\title{
Minimum Wages, Relative Wages, and Productivity: An Empirical Analysis on Indonesia Food and Beverage Industry
}

\author{
Ibnu Nur Hamzah ${ }^{1}$, Firmansyah ${ }^{1, *}$, Andi M. Alfian Parewangi ${ }^{2}$ \\ ${ }^{1}$ Department of Economic and Business, Universitas Diponegoro, Indonesia \\ ${ }^{2}$ Center for Fundamental Economic Analysis - Fundamental Asia, Department of Economics, University of Darussalam Gontor, \\ Indonesia
}

Received September 1, 2020; Revised January 11, 2021; Accepted January 20, 2021

\section{Cite This Paper in the following Citation Styles}

(a): [1] Ibnu Nur Hamzah, Firmansyah, Andi M. Alfian Parewangi , "Minimum Wages, Relative Wages, and Productivity: An Empirical Analysis on Indonesia Food and Beverage Industry," Universal Journal of Accounting and Finance, Vol. 9, No. 1, pp. 33 - 43, 2021. DOI: 10.13189/ujaf.2021.090104.

(b): Ibnu Nur Hamzah, Firmansyah, Andi M. Alfian Parewangi (2021). Minimum Wages, Relative Wages, and Productivity: An Empirical Analysis on Indonesia Food and Beverage Industry. Universal Journal of Accounting and Finance, 9(1), 33 - 43. DOI: 10.13189/ujaf.2021.090104.

Copyright@2021 by authors, all rights reserved. Authors agree that this article remains permanently open access under the terms of the Creative Commons Attribution License 4.0 International License

\begin{abstract}
Background of the research: Previous study on minimum wages policy in Indonesia mostly focused on employment and welfare effect, while its relationship with productivity is lack. Purpose: This study tends to study the wages and productivity relationship using minimum wages increase information in Indonesia. This paper aims to calculate the time varying productivity using one step production function then implements difference-in-difference technique to measure the productivity changes due to the implementation of minimum wages policy. Methodologies: We choose the case of food and beverage industry in Indonesia and find a strong support for efficiency wages theory. This research takes information from medium to large firms within food and beverages industry in several region in Indonesia as a sample. The reason why this research used this sample is the importance of food and beverages industry in Indonesian economy. Principal results: Using standard panel regression, this paper also find evidence on positive relationship between relative wages and productivity. Major conclusions: The findings showed that firms adopting minimum wages policy show higher changes in productivity compared to firm that is already above the minimum wages. Contributions to the field: the study made a good attempt to examine a critical issue of relationship between minimum wage policy and total factor
\end{abstract}

productivity changes for food industry in the context of Indonesia. Important aspects of the study: The important aspects of the study lie in the analysis of food demand as the indicator of agricultural markets.

Keywords Efficiency Wages, Minimum Wages, Productivity, Employment

JEL Classification Code: E24, D24, J24, J38

\section{Introduction}

Classical economist believes that the relationship between wages and productivity is created by perfect market mechanism that equalizes marginal productivity of labor and its wages. Thus, by this mechanism there will be no unemployment in the economy as level of wages automatically decrease in respond to higher supply of labor. This mechanism might work in traditional sector as there is no labor differentiation and no rigidity in labor market But this mechanism may not work in current labor market condition as there are rules that make labor market more rigid. 


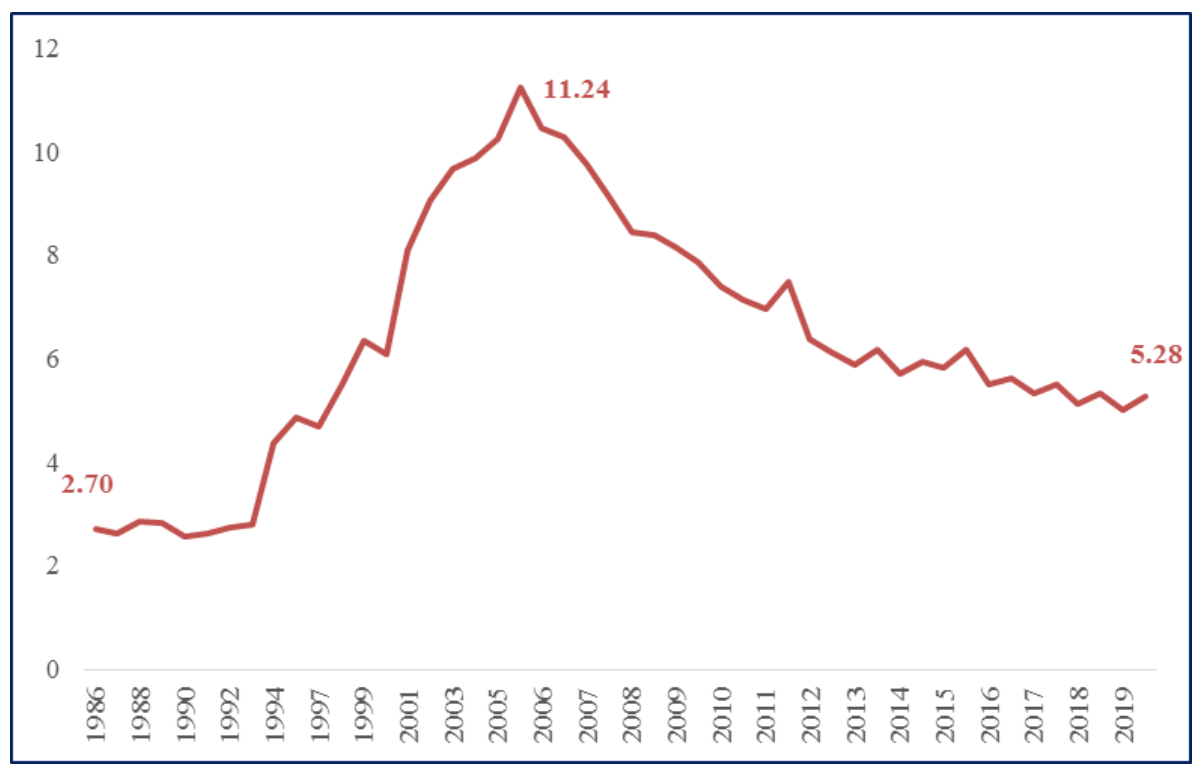

Figure 1. Indonesia Unemployment Rate 1986 - 2019

The implementation of minimum wages policy is one factor that shows rigidity in labor market. This policy has been implemented in many countries both in developed and developing nations. Higher wages created by this policy are expected to create more unemployment by perfect labor market mechanism, but there are many finding no negative employment effect from minimum wages policy [1]. In Indonesia case, it is also found that minimum wages policy implementation has no negative effect on employment [2, 3]. Indonesia unemployment rate is also keep decreasing after 1998 financial crisis until August 2019, while there are minimum wages increase every year.

This wages and productivity relationship are viewed differently by Akerlof [4]. Based on his view and findings, there are not just level of wages that define productivity but its relative is also able to unleash more productivity. This view can explain why it is rational for firm to stay above market clearing wage, thus wages stay above market clearing and create unemployment. On the other side, this view can explain why minimum wages implementation has no negative impact on employment and has positive impact on productivity because firms may increase their labor productivity instead of cutting employment.

Another feature of minimum wages policy implementation is that it can create compression of wage inequality. Based on efficiency wages theory, the compression of relative wages variation may create positive productivity effect because worker feel more equal and its spur resource reallocation towards more productive activities. Theoretical discussion and previous study show that relative wages variation plays an important role in defining labor productivity $[5,6]$.

Previous study on minimum wages policy in Indonesia mostly focused on employment and welfare effect, while its relationship with productivity is lack. This study tends to study the wages and productivity relationship using minimum wages increase information in Indonesia. This research takes information from medium to large firms within food and beverages industry in several region in Indonesia as a sample. The reason why this research used this sample is the importance of food and beverages industry in Indonesian economy.

The issue of wages and productivity relationship in food and beverages industry is relevant and very important for the following reasons; first, food demand is expected to increase in the range of 59\% to $98 \%$ by 2050 [7]. This trend will shape agricultural markets [8]. We take this as important background for the processed food and beverage industry to face similar challenge by the next thirty years from now as this industry uses input mostly from agricultural sector.

The second reason why the issue is important and highly relevant is the fact that investment in agriculture in most developing countries has declined over the last 30 years and much less is spent on $R \& D$ compared to developed countries-resulting in low productivity and stagnant production $[9,10]$. We are of the high interest to see this trend, and this paper assesses the labor productivity in food and beverage industry in developing country. 


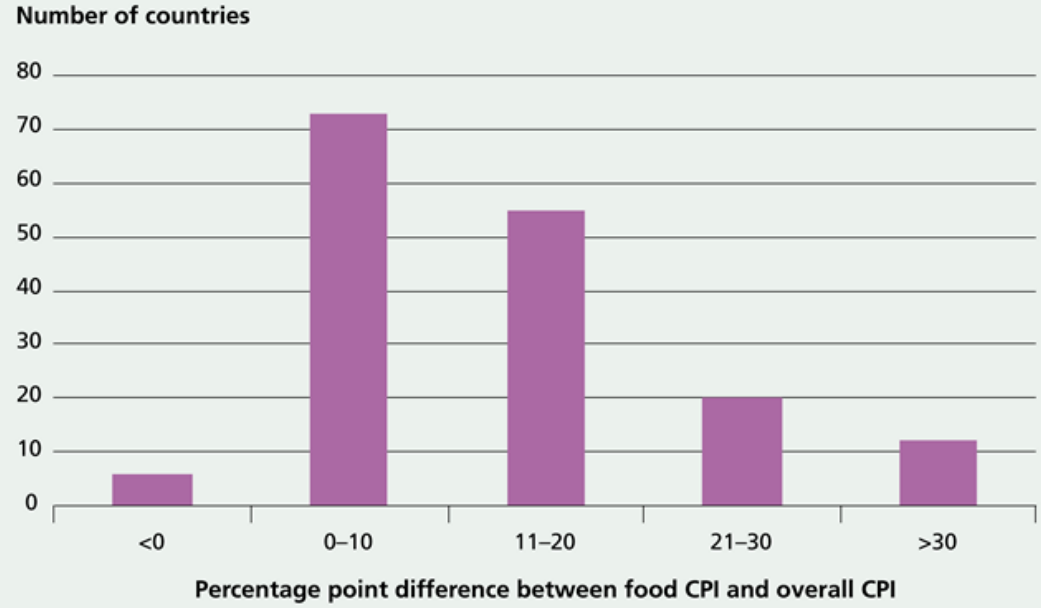

CPI is consumer price index. The vertical axis shows the number of countries for each group. Source: FAO, 2012 [10]

Figure 2. Average Difference between Food Prices and Overall Consumer Prices

The third reason to examine this issue is the fact that food is the major contributor of inflation in most economies. About 127 countries in the world experience higher food price up to 20 points relative to the CPI; this accounts about half countries in the world. More than 30 countries experience event higher difference up to 30 points. Only less than 10 countries in the world experience the opposite, where the food prices on their country are lower than the overall consumer prices. High functioning food and beverages industry may increase the efficiency of agricultural market by its ability to increase the age of food and beverages, thus reducing waste (Figure 1).

The fourth reason to underline is the fact that the food and beverage industries pose significant potency on distributing welfare and reducing poverty. Worldwide, the food and beverage industry are highly concentrated with a just a few companies controlling thousands of brands around the world. To mention the few is Nestle, the world's largest food and beverage company with 6000 brands, Kraft Foods that sells snacks in 170 countries, PepsiCo with their Frito-Lay and Quaker Oats [11] ${ }^{1}$. We lay this fourth reason even though we do not specifically analyze the welfare distribution and poverty. Instead, we use this motive to start analyzing the link between wages and the productivity in this sector.

Hypotheses to test on this paper are: (i), There is a efficiency wages effect in Indonesia food and beverages industry; (ii) There is positive effect of minimum wages policy on firm productivity; (iii) There is a positive relative wage effect on productivity. To answer this hypothesis, we estimate production function following Wooldridge [12]. To measure the impact of minimum

\footnotetext{
${ }^{1}$ Former US Director, UN World Food Program
}

wage policy, we use difference in difference estimation; while the link is between wage and labor productivity we utilize standard panel data estimation. The results from difference-in-difference and panel data estimation used to support efficiency wages effect hypothesis.

Estimation result shows that firms adopting minimum wages policy show higher changes in productivity compared to firm that is already above the minimum wages. Furthermore, we also show that firms relative wages have significant effect on their productivity. These conclusions are robust across several years of new minimum wages introduction for the impact of minimum wages policy and several estimation techniques for relative wages effect on productivity.

The next section of this paper analyze the literature studies. Section three discusses the data and estimation method, while section four discusses the result and its analysis. Section five provides conclusion and will close the presentation of this paper.

\section{Literature Review and Hypothesis}

\subsection{Wages and Productivity Relationship}

The relationship between wages and productivity is first viewed differently by Akerlof [4]. His findings show worker with higher wages tend to give extra effort in doing their job as a gratitude for their employer. From this finding, it is said that the worker voluntarily increases their productivity because they got higher wages compared to other employee in another firms. The theory behind this relationship is equity theory, relative deprivation theory, and social exchange theory. Thus, this view gained much attention among economic literature. 
There is also development in theoretical literature based on Akerlof [4] findings as it creates new feature in economic theory. First, it is rational for firm to stay above market clearing wage as they want to motivate their employee to stay above their competitor [6]. Second, it is rational for firm to give higher wage to increase employee opportunity cost in losing their job [13]. Third, it causes unemployment rate will not be able to arrive at zero point because wages stay at above market clearing wages [13].

As we follow Summers [6], there will be a productivity addition if one firm gives their worker higher wages compared to another firms in one location. This effect is based on efficiency wages hypothesis as it said that worker voluntarily increases their productivity as a gratitude for their employer that gives them more wages. Thus, not only wages define marginal productivity of labor, but their relative wages also play role in productivity determination. The relation between relative wage and productivity is also found by the study conducted in Sweden as the economy experiencing huge relative wage compression and decompression [5]. As firm managers are aware about this effect, then it will create macroeconomy impact that causes wages stays above market clearing rate, thus it creates unemployment [14].

Table 1. Previous Wages and Productivity Studies

\begin{tabular}{|c|c|c|c|c|}
\hline Year & Researcher & Main Objective & Method & Findings \\
\hline 2013 & $\begin{array}{l}\text { Mărginean \& } \\
\text { Chenic }\end{array}$ & $\begin{array}{l}\text { Updates on current empirical } \\
\text { proof about minimum wages } \\
\text { theory and idea. }\end{array}$ & Literature review & $\begin{array}{l}\text { Most empirical findings show no impact of } \\
\text { minimum wages policy on unemployment, so } \\
\text { they conclude that this type of study is no } \\
\text { longer relevant. }\end{array}$ \\
\hline 2013 & Magruder & $\begin{array}{l}\text { Proof that minimum wages } \\
\text { policy causes a big push in } \\
\text { Indonesian economy }\end{array}$ & $\begin{array}{l}\text { Spatial regression } \\
\text { discontinuity }\end{array}$ & $\begin{array}{l}\text { Found positive impact of minimum wages } \\
\text { policy on formal sector but opposite on } \\
\text { informal sector. Based on these findings, he } \\
\text { concludes that minimum wages support big } \\
\text { push }\end{array}$ \\
\hline 2000 & $\begin{array}{l}\text { Hibbs Jr. \& } \\
\text { Locking }\end{array}$ & $\begin{array}{l}\text { Show the effect of wage } \\
\text { dispersion and productivity in } \\
\text { Sweden }\end{array}$ & Multiple Regression & $\begin{array}{l}\text { Reduction of interindustry wage differentials } \\
\text { evidently did, however, contribute positively } \\
\text { to aggregate output and productivity growth }\end{array}$ \\
\hline 2008 & Alatas \& Cameron & $\begin{array}{l}\text { Found the impact of minimum } \\
\text { wages on unemployment }\end{array}$ & Quasi experimental & $\begin{array}{l}\text { Found no negative impact of minimum wages } \\
\text { policy on big firms in Indonesia. }\end{array}$ \\
\hline 2012 & $\begin{array}{c}\text { Del Carpio, } \\
\text { Nguyen, \& Wang }\end{array}$ & $\begin{array}{l}\text { Found the impact of minimum } \\
\text { wages on unemployment }\end{array}$ & Quasi experimental & $\begin{array}{l}\text { The impact is varied among manufacturing } \\
\text { firms in Indonesia, smaller firms tend to have } \\
\text { negative impact while bigger firms are less } \\
\text { affected. }\end{array}$ \\
\hline 2001 & Rama & $\begin{array}{l}\text { Found the impact of double } \\
\text { minimum wages increase on } \\
\text { unemployment }\end{array}$ & $\begin{array}{l}\text { Multiple regression } \\
\text { dummy variable }\end{array}$ & $\begin{array}{l}\text { The impact is different between small and big } \\
\text { firms, where smaller firms have negative } \\
\text { impact while bigger firms. }\end{array}$ \\
\hline 2008 & $\begin{array}{l}\text { Draca, Machin, } \\
\text { dan Reenen }\end{array}$ & $\begin{array}{l}\text { Found the impact of double } \\
\text { minimum wages increase on } \\
\text { firms profit }\end{array}$ & Quasi experimental & $\begin{array}{l}\text { For the case of firms in England, minimum } \\
\text { wages policy has negative impact on firms } \\
\text { profit. }\end{array}$ \\
\hline 2016 & Long \& Yang & $\begin{array}{l}\text { Found the impact of double } \\
\text { minimum wages increase on } \\
\text { firms profit }\end{array}$ & Multiple Regression & $\begin{array}{l}\text { For the case of firms in China, minimum } \\
\text { wages policy has negative impact on firms } \\
\text { profit. }\end{array}$ \\
\hline 2013 & Georgiadis & $\begin{array}{l}\text { Proofing minimum } \text { wages } \\
\text { prevail as efficiency } \\
\text { effect }\end{array}$ & Quasi experimental & $\begin{array}{l}\text { Minimum wages cause firms supervision cost } \\
\text { to decrease }\end{array}$ \\
\hline 2010 & Owens \& Kagel & $\begin{array}{l}\text { Found the impact of double } \\
\text { minimum wages increase on } \\
\text { labor productivity }\end{array}$ & Quasi experimental & $\begin{array}{l}\text { For the case of firms in England, minimum } \\
\text { wages policy has positive impact on labor } \\
\text { productivity. }\end{array}$ \\
\hline 2004 & $\begin{array}{l}\text { Galindo-Rueda \& } \\
\text { Pereira }\end{array}$ & $\begin{array}{l}\text { Found the impact of double } \\
\text { minimum wages increase on } \\
\text { firm productivity }\end{array}$ & Quasi experimental & $\begin{array}{l}\text { For the case of firms in England, minimum } \\
\text { wages policy has positive impact on firm } \\
\text { productivity. }\end{array}$ \\
\hline 2016 & $\begin{array}{l}\text { Rizov, Croucher, } \\
\text { \& Lange }\end{array}$ & $\begin{array}{l}\text { Found the impact of double } \\
\text { minimum wages increase on } \\
\text { firm productivity }\end{array}$ & Quasi experimental & $\begin{array}{l}\text { Minimum wages policy has positive impact } \\
\text { on firm productivity, the impact is higher in } \\
\text { England. }\end{array}$ \\
\hline 2015 & $\begin{array}{l}\text { Riley \& } \\
\text { Bondibene }\end{array}$ & $\begin{array}{l}\text { Found the impact of double } \\
\text { minimum wages increase on } \\
\text { labor productivity }\end{array}$ & Quasi experimental & $\begin{array}{l}\text { Minimum wages policy has positive impact } \\
\text { on labor productivity and firm productivity. }\end{array}$ \\
\hline
\end{tabular}


There is another reason that makes it rational for firms to keep their wages higher than market clearing wages as documented by [13]. By setting their wages higher, firm is making their worker opportunity cost of losing the job become higher. This creates worker self-awareness to avoid shirking behavior as shirking may cause them losing the job and firms may lower supervision cost [15].

Another cause wage always stays at above market clearing is government policy in setting minimum wages. This policy enables firms to adjust their wage below certain line in response to higher labor supply. This policy is also forcing firms with low productivity to increase their productivity or exit from the market. While this policy may cause higher unemployment rate because higher supply of labor, several studies have shown that there is no increase in unemployment because minimum wages increases [2, 3, 1]. Therefore, firms must increase their cost and decrease their profit as employee structure does not change in rising minimum wages or firms may adjust their productivity to close the gap and keep profit rate unchanged [16, 17]. We have documented several studies that relate wages and productivity in Table 1.

We have shown that many previous studies found relationship between wages and productivity, especially related to minimum wages implementation. Several studies found that minimum wages policy increases labor and firm productivity while the other shows that it decreases firm profit. These findings are also the reason why many previous studies were unable to found unemployment effect of minimum wages policy.

\subsection{Minimum Wages Policy Research in Indonesia}

There are several studies about minimum wages policy implementation in Indonesia but most of them are focused heavily on its employment effect or welfare, while the effect on employment may be limited as previous study found in several countries [1]. Limited effect of minimum wages policy implementation on employment in Indonesia is expected because of lower obedience rate and high portion of Indonesia worker in informal sector [18]. This low obedience rate might also create ineffective minimum wages policy in increasing welfare. In contrast, study conducted by Magruder [3] shows minimum wages policy in Indonesia might create a big push by increasing formal employment rate and decreasing informal employment rate.

Minimum wages in Indonesia increase sharply between 1990 and 1996, from this sharp increase Alatas \& Cameron. [2] shows no negative employment impact for large establishment but worker in smaller establishment may have suffered from job losses as a result of minimum wages increase. This finding suggests that larger firms can adjust its cost structure or revenue other than adjusting their employment structure. Larger firms may also have good management quality that is able to increase its productivity as cost of labor increase by minimum wages policy.

The effect of minimum wages policy in Indonesia is also found to reduce wage inequality [19]. This effect is significant because minimum wages enforce firms below minimum wages line to increase its wage, so the difference among firms decreases. This effect is important because there may be productivity related effect from more equal wages as proposed by efficiency wages hypothesis and may effect resource allocation towards more productive activities as found in Sweden wages variation compression and decompression study by Hibbs Jr. \& Locking [5]. Moreover, the relationship of relative wages and productivity is also found to be matched with the theory and previous study that we found [5, 20, 21].

\subsection{Research Objectives and Hypotheses}

This research aims to understand the wages and productivity relationship to fill the gap in the literature of minimum wages policy impact in Indonesia. We have formulated several hypotheses to answer our research objective based on theoretical framework and previous studies on wages and productivity relationship. We formulate one hypothesis that exploits minimum wages policy implementation in Indonesia and one hypothesis that relates relative wages difference between firms to understand wages-productivity relationship as formulated by Akerlof [4]. We used sample from medium to large firms in food and beverages industry to answer the hypothesis as this industry play major role in Indonesian manufacture.

1. Firms that adjust their wages after the introduction of new minimum wages policy have higher productivity change compared to another firms. This hypothesis is based on argument that firms tend to increase their productivity instead of cutting employment in respond to minimum wages increase as there is no negative effect on employment after minimum wages increase in Indonesia especially for large establishment [2]. Higher productivity is also expected from efficiency wages effect that sourced from the compression of relative wages variation as minimum wages policy in Indonesia found to decrease wage inequality [19]. Another source that may increase firm productivity after minimum wages increase is resource reallocation towards more productive activities [5].

2. Relative wages have positive effect on firm productivity. This hypothesis is based on efficiency wages theory and previous empirical findings on wages and productivity relationship. This hypothesis is used to support the explanation of hypothesis 1. 


\section{Methods}

This research employs methodology that was mostly used in previous studies that we found to proof our hypotheses. We separate the methodology in three parts, (1) productivity estimation, (2) standard panel data regression to proof wages and relative wages relationship with firm productivity, and (3) natural experiment using minimum wages policy implementation to understand wages and productivity relationship.

\subsection{Data and Variables}

This research uses firm level data from Medium-Large Manufacturing Firm Survey Indonesian Statistical Agency for the period of 2010 - 2015. Other data are taken from Indonesia's Central Bureau of Statistics (regional consumer price index) and local government decree (minimum wages). Table 2 is the description of variable used in this research.

Table 2. Description of Variable used in this research

\begin{tabular}{|c|c|c|}
\hline Variable & Code & Description \\
\hline Value of Output & $\mathrm{Y}$ & Firm total production value using constant price. \\
\hline Production Worker & $\mathrm{L}$ & Daily average of total production worker in one year. \\
\hline Capital & K & Estimated of firm total fixed asset in year of survey using constant price. \\
\hline Raw Material & $\mathrm{R}$ & Firm total raw material value using constant price. \\
\hline Deflator & CPI & Regional Consumer Price Index \\
\hline $\begin{array}{l}\text { Production Worker } \\
\text { Income per capita }\end{array}$ & WAGEP & $\begin{array}{l}\text { Total of production worker income in one year using constant price per Number of Production } \\
\text { Worker }\end{array}$ \\
\hline Minimum Wages & MWAGE & Regional minimum wages based on each region decree \\
\hline Relative Wages & rw & Ratio of production worker income per capita and its average in each location. \\
\hline Treatment & $\mathrm{T}$ & $\begin{array}{l}\qquad T_{i}\left\{\begin{aligned} 1 \text { if } W A G E_{i t-1}< & M W A G E_{i t} \times L_{i t} \times 12<W A G E_{i t} \\
& 0 \text { otherwhise }\end{aligned}\right. \\
\text { where } W A G E_{i t} \text { is total of production worker income in one year and } M W A G E_{i t} \text { is regional } \\
\text { minimum wages. }\end{array}$ \\
\hline Period Dummy & $\mathrm{D}$ & $D_{t}\left\{\begin{array}{c}1: \text { Period for } t \\
0: \text { Period for } t-1\end{array}\right.$ \\
\hline $\begin{array}{l}\text { Dummy Interaction } \\
T_{i} \text { and } D_{t}\end{array}$ & TD & Dummy interaction $\left(T_{i} * D_{t}\right)$ to calculate the effect of minimum wages policy. \\
\hline $\begin{array}{l}\text { Total Factor } \\
\text { Productivity (TFP) }\end{array}$ & $\mathrm{P}$ & Calculated using equation (3.2.2a) based on estimated production function parameter \\
\hline Labor Productivity & LP & Calculated using equation (3.2.2a) based on estimated production function parameter \\
\hline Capital Productivity & KP & Calculated using equation (3.2.2a) based on estimated production function parameter \\
\hline
\end{tabular}




\subsection{Production Function Estimation and Productivity Calculation}

This research employs Cobb-Douglas production function to calculate productivity. Production function parameters are estimated using one step production function estimation as proposed by Wooldridge [11]. Using linearized CD production function,

$$
y_{i t}=\alpha+w_{i t} \beta+x_{i t} \gamma+v_{i t}+e_{i t},
$$

where all variables denoted in lowercase are in natural logarithmic form, $\boldsymbol{w}_{i t}$ is $1 \mathrm{x} \mathrm{J}$ vector of input variable, $\boldsymbol{w}_{i t}$ is $1 \mathrm{x} \mathrm{K}$ vector of fixed variable, $v_{i t}$ is unobserved productivity, and $e_{i t}$ is white noise.

Wooldridge (2009) accommodated previous model proposed by Olley Pakes (OP) dan Levinsohn Petrin (LP) to offer one step production function estimation using Generalized Method of Moment. Moments condition is derived from production function characteristics as in OP and LP. This method is using raw material as a proxy for productivity as in LP.

In executing Wooldridge [11] production function estimation, we employ prodest module in Stata. Prodest is developed by Mollisi and Rovigatti [22] to provide several productivity estimation techniques including one proposed by Wooldridge [11]. Input variable $\left(\boldsymbol{w}_{i t}\right)$ used in the calculation is number of production worker in natural logarithmic form, and fixed variable $\left(\boldsymbol{x}_{i t}\right)$ is total estimated fixed asset using constant price in natural logarithmic form and uses raw material for productivity proxy $\left(\boldsymbol{m}_{i t}\right)$.

Estimated parameter is used to calculate total factor productivity $\left(P_{i t}\right)$, labor productivity $\left(L P_{i t}\right)$, and capital productivity $\left(K P_{i t}\right)$ using this equation.

$$
\begin{gathered}
p_{i t}=y_{i t}-\left(\beta * l_{i t}+\gamma * k_{i t}\right) \\
l p_{i t}=\ln \left(\beta * \frac{Y_{i t}}{L_{i t}}\right) \\
k p_{i t}=\ln \left(\gamma * \frac{Y_{i t}}{K_{i t}}\right)
\end{gathered}
$$

\subsection{Detecting Efficiency Wages Effect}

This research exploits minimum wages policy as a natural experiment to understand wages and productivity relationship using difference-in-difference technique. This method is used because it is able to support research objectives as it used by previous study similar to this research $[16,23]$. Using standard difference-in-difference equation,

$$
P_{i t}=\alpha+\gamma T_{i}+\beta D_{p=1}+\delta\left(T_{i} * D_{p=1}\right)+\varepsilon_{i t}
$$

where $P_{i t}$ is total factor productivity, $T_{i}$ is firm that affected by minimum wages policy, $D_{t}$ is dummy for denoting time before and after minimum wages policy, and $\varepsilon_{i t}$ is error term.

This research also used standard panel regression technique to understand efficiency wages hypothesis using relative wages information.

$$
\begin{array}{rr}
p_{i t}=\alpha+\beta_{1} r w_{i t}+\beta_{2} \text { wagep }_{i t}+\beta_{3} \text { size }_{i t}+\beta_{4} A G E_{i t}+ \\
\beta_{5} D L O C_{i}+\beta_{6} D U R B_{i}+\varepsilon 1_{i t} & (3.3 .2 \mathrm{a}) \\
l p_{i t}=b+\beta_{7} r w_{i t}+\beta_{8} \text { wagep }_{i t}+\beta_{9} A G E_{i t}+ \\
\beta_{10} D L O C_{i}+\beta_{11} D U R B_{i}+\varepsilon 2_{i t} & (3.3 .2 \mathrm{~b}) \\
k p_{i t}=c+\beta_{12} \text { Size }_{i t}+\beta_{13} A G E_{i t}+\beta_{14} D L O C_{i}+ \\
\beta_{15} D U R B_{i}+\varepsilon 2_{i t}
\end{array}
$$

Parameters in equation (3.3.2) are estimated using several panel data regression techniques (fixed effect, random effect, and maximum likelihood) to make sure the consistency of relationship.

Estimation results from equation (3.3.1) and (3.3.2) are used to support efficiency wages hypothesis. The presence of this effect in the economy is supported if the result from (3.3.1) found positive relationship between

\begin{tabular}{|c|c|c|c|}
\hline No & Region & $\begin{array}{l}\text { Number of } \\
\text { Firms }\end{array}$ & $\begin{array}{c}\% \text { of Total Firms in } \\
\text { Food and Beverages } \\
\text { Industry }\end{array}$ \\
\hline 1 & Sidoarjo, East Java & 82 & 3.99 \\
\hline 2 & $\begin{array}{c}\text { Kebumen, Central } \\
\text { Java }\end{array}$ & 77 & 3.75 \\
\hline 3 & $\begin{array}{c}\text { Banyuwangi, East } \\
\text { Java }\end{array}$ & 71 & 3.45 \\
\hline 4 & Garut, West Java & 65 & 3.16 \\
\hline 5 & Cirebon, West Java & 63 & 3.06 \\
\hline 6 & Pati, Central Java & 58 & 2.82 \\
\hline 7 & Indramayu, West Java & 47 & 2.29 \\
\hline 8 & Jember, East Java & 42 & 2.04 \\
\hline 9 & $\begin{array}{l}\text { Asahan, North } \\
\text { Sumatra }\end{array}$ & 39 & 1.90 \\
\hline 10 & Kediri, East Java & 39 & 1.90 \\
\hline 11 & Surabaya, East Java & 34 & 1.65 \\
\hline 12 & $\begin{array}{c}\text { Tulungagung, East } \\
\text { Java }\end{array}$ & 31 & 1.51 \\
\hline 13 & $\begin{array}{l}\text { Makassar, South } \\
\text { Sulawesi }\end{array}$ & 31 & 1.51 \\
\hline \multirow[t]{2}{*}{14} & Pasuruan, East Java & 30 & 1.46 \\
\hline & Total & 709 & 34.48 \\
\hline
\end{tabular}
minimum wages policy and productivity and the results from (3.3.2) found positive relationship between relative wages and productivity.

\section{Results and Discussion}

\subsection{Selection and Description of Areas}

This research selects several regions that have relatively huge concentration of food and beverages firm. Selected region has at least 30 firm samples within 2010 - 2015 period. Table 3 reports all the region used in this research.

Table 3. Number of Firms in Selected Region

\subsection{Production Function Estimation Results}

Estimated production function parameters are used to calculate firm's productivity in each period. Variables 
used to estimate production function is firm output, capital, production worker, and raw material. All variables are estimated in its natural logarithmic form. Table 4 reports its descriptive statistics.

Table 4. Production Function Variables Descriptive Statistics

\begin{tabular}{ccccc}
\hline \multirow{2}{*}{ Statistics } & \multicolumn{5}{c}{ Variables } \\
\cline { 2 - 5 } & $\boldsymbol{y}$ & $\boldsymbol{k}$ & $\boldsymbol{l}$ & $\boldsymbol{r}$ \\
\hline Mean & 14.82 & 13.04 & 3.54 & 14.21 \\
Maximum & 23.55 & 26.25 & 8.34 & 23.32 \\
Minimum & 9.85 & 6.03 & 0.69 & 6.33 \\
Standard Deviation & 1.83 & 1.95 & 0.95 & 1.92 \\
\hline
\end{tabular}

Source: Author calculation

Table 5 reports the estimation results. All estimated coefficient shows positive sign as predicted by theory and has strong significance level. The result of Wald constant return to scale test shows that this estimated production function is not following constant return to scale.

Table 5. Production Function Estimation Results

\section{Wooldridge (2009) Productivity Estimator}

Observation: 3610

Group: 722

Wald test on constant return to scale: $\mathrm{Chi} 2 \mathbf{= 8 , 6 1}$, $\mathrm{p}$-value $=\mathbf{0 , 0 0}$

\begin{tabular}{ccccccc}
\hline$y$ & Coef. & Std. Err. & $\mathrm{z}$ & $\mathrm{P}>\mathrm{z}$ & \multicolumn{2}{c}{ [95\% Conf. Interval] } \\
\hline$l$ & 0.21 & 0.01 & 16.30 & 0.00 & 0.18 & 0.24 \\
$k$ & 0.05 & 0.01 & 4.97 & 0.00 & 0.03 & 0.08 \\
$r$ & 0.80 & 0.02 & 32.93 & 0.00 & 0.75 & 0.85 \\
\hline
\end{tabular}

Source: Author calculation

Table 6 and Table 7 respectively show descriptive statistics used in the model we estimate and correlation matrix between independent variables. From the tables, we make sure that we did not faced by multicollinearity problem. The highest correlation coefficient is between wage per capita and relative wage, but it is still relatively low $<0.8$ to cause multicollinearity problem.
Table 6. Descriptive Statistics of Relative Wages Related Variables

\begin{tabular}{cccccccc}
\hline \multirow{2}{*}{ Statistics } & \multicolumn{8}{c}{ Variables } \\
\cline { 2 - 8 } & wagep & $\boldsymbol{r w}$ & size & age & $\boldsymbol{p}$ & $\boldsymbol{l p}$ & $\boldsymbol{k p}$ \\
\hline Mean & 8.8 & -0.1 & 3.54 & 16.02 & 13.3 & 9.74 & -1.06 \\
Maximum & 15.28 & 49.64 & 8.34 & 107 & 21.11 & 16.62 & 6.57 \\
Minimum & 4.79 & -0.99 & 0.69 & 0 & 8.52 & 5.22 & -9.97 \\
Standard Deviation & 1.69 & 1.13 & 0.95 & 16.2 & 1.63 & 1.44 & 1.51 \\
\hline
\end{tabular}

Source: Author calculation

Table 7. Correlation Matrix of Relative Wages Related Variables

\begin{tabular}{ccccc}
\hline & wagep & rw & size & age \\
\hline wagep & 1.00 & & & \\
rw & 0.51 & 1.00 & & \\
size & 0.10 & 0.02 & 1.00 & \\
age & 0.16 & 0.05 & 0.23 & 1.00 \\
\hline
\end{tabular}

Source: Author calculation

First to discuss is natural experiment of wages and productivity relationship based on minimum wages increase every year during 2011 - 2015 in Indonesia. The results of minimum wages increase are found to have positive effect on firm productivity in food and beverages industry. Table 8 show positive significant sign in interaction variable in most year of minimum wages increase, only for year 2013 that shows different sign. These results imply that firms which previously operate under minimum wages and adjust its wages to match minimum wages have higher productivity change compared to another firms.

We believe that these results are robust because there is consistent strong positive effect in most observation period. The effect in year 2012 - 2013 is excluded because there may have another effect from economic crisis that causes productivity to decrease. In year 2012 both labor and capital productivity increase but not significant so the sign of total factor productivity is still positive and we can still high confidence for positive effect, while in 2013 we have weak negative effect on labor productivity and positive effect on capital productivity so in total we have insignificant positive effect on total factor productivity. 
Table 8. Estimation Results for Minimum Wages Effect on Productivity

\begin{tabular}{|c|c|c|c|c|c|c|c|c|c|}
\hline \multirow{3}{*}{ Year } & \multirow{3}{*}{$\begin{array}{c}\text { Variables } \\
p\end{array}$} & \multicolumn{8}{|c|}{ Variables, p-value in () } \\
\hline & & \multicolumn{2}{|c|}{$T_{i}$} & \multicolumn{2}{|c|}{$D_{p=1}$} & \multicolumn{2}{|c|}{$T_{i} * D_{p=1}$} & \multicolumn{2}{|c|}{ Constant } \\
\hline & & $0.619^{* *}$ & $(0.00)$ & -0.035 & $(0.30)$ & $0.723^{* *}$ & $(0.00)$ & $13.06^{* *}$ & $(0.00)$ \\
\hline \multirow[t]{3}{*}{2011} & $l p$ & $0.334^{*}$ & $(0.01)$ & $-0.153^{* *}$ & $(0.00)$ & $0.695^{* *}$ & $(0.00)$ & $9.651^{* *}$ & $(0.00)$ \\
\hline & $k p$ & $-0.323^{*}$ & $(0.02)$ & 0.044 & $(0.27)$ & $0.622^{* * *}$ & $(0.00)$ & $-1.172^{* *}$ & $(0.00)$ \\
\hline & $p$ & $-1.307^{* *}$ & $(0.00)$ & -0.006 & $(0.88)$ & $0.121^{\dagger}$ & $(0.08)$ & $13.83^{* *}$ & $(0.00)$ \\
\hline \multirow[t]{3}{*}{2012} & $l p$ & $-1.121^{* *}$ & $(0.00)$ & 0.009 & $(0.84)$ & 0.073 & $(0.27)$ & $10.17^{* *}$ & $(0.00)$ \\
\hline & $k p$ & 0.018 & $(0.87)$ & -0.058 & $(0.34)$ & 0.092 & $(0.30)$ & $-1.089^{* *}$ & $(0.00)$ \\
\hline & $p$ & $0.684^{* *}$ & $(0.00)$ & -0.009 & $(0.76)$ & 0.052 & $(0.46)$ & $13.15^{* *}$ & $(0.00)$ \\
\hline \multirow[t]{3}{*}{2013} & lp & $0.674^{* *}$ & $(0.00)$ & 0.025 & $(0.43)$ & -0.074 & $(0.30)$ & $9.569^{* *}$ & $(0.00)$ \\
\hline & $k p$ & -0.228 & $(0.11)$ & -0.003 & $(0.94)$ & $0.244^{*}$ & $(0.02)$ & $-1.050^{* *}$ & $(0.00)$ \\
\hline & $p$ & $0.572^{* *}$ & $(0.00)$ & $0.069^{\dagger}$ & $(0.08)$ & $0.368^{* *}$ & $(0.00)$ & $13.19^{* *}$ & $(0.00)$ \\
\hline \multirow[t]{3}{*}{2014} & lp & $0.545^{* * *}$ & $(0.00)$ & $0.078^{* *}$ & $(0.04)$ & $0.273^{* * *}$ & $(0.00)$ & $9.623^{* *}$ & $(0.00)$ \\
\hline & $k p$ & -0.004 & $(0.97)$ & 0.030 & $(0.56)$ & $0.398^{* *}$ & $(0.00)$ & $-1.050^{* *}$ & $(0.00)$ \\
\hline & $p$ & $0.451^{*}$ & $(0.01)$ & -0.048 & $(0.15)$ & $0.408^{* *}$ & $(0.00)$ & $13.36^{* *}$ & $(0.00)$ \\
\hline \multirow[t]{2}{*}{2015} & $l p$ & $0.626^{* *}$ & $(0.00)$ & -0.004 & $(0.90)$ & $0.289^{* *}$ & $(0.00)$ & $9.766^{* *}$ & $(0.00)$ \\
\hline & $k p$ & $-0.307^{\dagger}$ & $(0.10)$ & -0.070 & $(0.13)$ & $0.362^{* *}$ & $(0.00)$ & $-0.916^{* *}$ & $(0.00)$ \\
\hline
\end{tabular}

Source: Author calculation

To support the explanation of Table 9, it reports the estimation results of relative wages and productivity relationship.

The second estimation results are reported in Table 9 supporting argument for efficiency wages effect. The results show positive significant effect of relative wages on total productivity and labor productivity. This relationship is consistent among 3 models reported in the table. This result is a strong indication that efficiency wages effect exists in Indonesia food and beverages industry and there may the cause for firm productivity increase after the increase of minimum wages that compress the relative wages variation.

Strong indication of minimum wages effect positive impact on productivity is supported by these findings. Evidence from Table 6 showed how minimum wages have a positive impact on firm productivity, while Table 9 shows positive relationship between relative wages and productivity. This may explain why there is no negative employment effect from minimum wages increase, as firms are able to increase their productivity after adjusting to minimum wages. The source of productivity increases may be explained by evidence from Table 4.6, as relative wages have significant effect on firm productivity, the compression of relative wages experienced by firms that adjust their wages to minimum wages increases their labor and total factor productivity. 
Table 9. Estimation Results for Relative Wages and Productivity Relationship

\begin{tabular}{|c|c|c|c|c|c|c|c|c|c|}
\hline \multirow{3}{*}{ Independent Variables } & \multicolumn{9}{|c|}{ Dependent Variables } \\
\hline & \multicolumn{3}{|c|}{$\mathbf{p}$} & \multicolumn{3}{|c|}{ lp } & \multicolumn{3}{|c|}{ kp } \\
\hline & [1] & [2] & [3] & [1] & [2] & [3] & [1] & [2] & [3] \\
\hline \multirow[t]{2}{*}{ constant } & $11.27^{* *}$ & $10.23^{* *}$ & $10.51^{* *}$ & $9.161^{* *}$ & $8.691^{* *}$ & $8.763^{* *}$ & $-3.034^{* *}$ & $-2.366^{* *}$ & $-2.369^{* *}$ \\
\hline & $(0.00)$ & $(0.00)$ & $(0.00)$ & $(0.00)$ & $(0.00)$ & $(0.00)$ & $(0.00)$ & $(0.00)$ & $(0.00)$ \\
\hline \multirow[t]{2}{*}{ size $_{i t}$} & $0.419^{* *}$ & $0.576^{* *}$ & $0.518^{* * *}$ & - & - & - & $0.556^{* *}$ & $0.447^{* *}$ & $0.447^{* *}$ \\
\hline & $(0.00)$ & $(0.00)$ & $(0.00)$ & & & & $(0.00)$ & $(0.00)$ & $(0.00)$ \\
\hline \multirow[t]{2}{*}{$a g e_{i t}$} & - & $0.012^{* *}$ & $0.014^{* *}$ & - & $0.011^{* *}$ & $0.013^{* *}$ & - & $-0.013^{* * *}$ & $-0.013^{* *}$ \\
\hline & & $(0.00)$ & $(0.00)$ & & $(0.00)$ & $(0.00)$ & & $(0.00)$ & $(0.00)$ \\
\hline \multirow[t]{2}{*}{ wagep $_{i t}$} & $0.062^{* *}$ & $0.084^{* *}$ & $0.072^{* *}$ & $0.067^{* *}$ & $0.088^{* *}$ & $0.077^{* *}$ & - & - & - \\
\hline & $(0.00)$ & $(0.00)$ & $(0.00)$ & $(0.00)$ & $(0.00)$ & $(0.00)$ & & & \\
\hline \multirow[t]{2}{*}{$r w_{i t}$} & $0.074^{\dagger}$ & $0.097^{*}$ & $0.09^{* *}$ & $0.09^{*}$ & $0.107^{*}$ & $0.102^{* *}$ & - & - & - \\
\hline & $(0.07)$ & $(0.04)$ & $(0.00)$ & $(0.05)$ & $(0.04)$ & $(0.00)$ & & & \\
\hline \multirow[t]{2}{*}{$D_{U R B_{i}}$} & - & $0.898^{* *}$ & $0.919^{* *}$ & - & $0.893^{* *}$ & $0.888^{* *}$ & - & $-0.34^{\dagger}$ & $-0.34^{*}$ \\
\hline & & $(0.00)$ & $(0.00)$ & & $(0.00)$ & $(0.00)$ & & $(0.08)$ & $(0.03)$ \\
\hline \multirow[t]{2}{*}{$D L O C_{i}$} & - & 0.00702 & 0.0034 & - & 0.0417 & 0.0446 & - & $-0.165^{* * *}$ & $-0.165^{* *}$ \\
\hline & & $(0.83)$ & $(0.91)$ & & $(0.23)$ & $(0.16)$ & & $(0.00)$ & $(0.00)$ \\
\hline Observation & 4332 & 4332 & 4332 & 4332 & 4332 & 4332 & 4332 & 4332 & 4332 \\
\hline \multicolumn{10}{|l|}{ (): p-value } \\
\hline \multicolumn{10}{|c|}{$* * / * / \dagger$ are significance sign sign for $0,01 / 0,05 / 0.1$} \\
\hline \multicolumn{10}{|c|}{ [1]: fixed effect robust standard error } \\
\hline \multicolumn{10}{|c|}{ [2]: random effect robust standard error } \\
\hline [3]: maximum likelihood & & & & & & & & & \\
\hline
\end{tabular}

Source: Author calculation 


\section{Conclusions}

This research found supporting evidence on efficiency wages theory, where minimum wages may increase firm productivity thus it is not creating unemployment. The relationship of relative wages and productivity is also found to be matched with the theory and previous study. This relationship may explain the source of firm productivity increase after adjusting their wage to accommodate minimum wages policy. This research findings suggest that minimum wages policy is important tool to create more equitable distribution of wages, while it may also be used to spur productivity and thus development process.

\section{REFERENCES}

[1] Mărginean S, Chenic AȘ. Effects of raising minimum wage: Theory, evidence and future challenges. Procedia Economics and Finance. 2013 Jan 1;6:96-102. https://doi.org/10.1016/S2212-5671(13)00119-6.

[2] Alatas V, Cameron LA. The impact of minimum wages on employment in a low-income country: a quasi-natural experiment in Indonesia. ILr review. 2008 Jan;61(2):201-23. https://doi.org/10.1177\%2F001979206376147204.

[3] Magruder JR. Can minimum wages cause a big push? Evidence from Indonesia. Journal of Development Economics. 2013 Jan 1;100(1):48-62. https://doi.org/10.101 6/j.jdeveco.2012.07.003.

[4] Akerlof GA. Labor contracts as partial gift exchange. The quarterly journal of economics. 1982 Nov 1;97(4):543-69. https://doi.org/10.2307/1885099.

[5] Hibbs Jr DA, Locking H. Wage dispersion and productive efficiency: Evidence for Sweden. Journal of Labor Economics. 2000 Oct;18(4):755-82.. https://doi.org/10.108 6/209976.

[6] Summers LH. Relative Wages, Efficiency Wages, and Keynesian Unemployment. The American Economic Review. 1988 May 1;78(2):383-8. https://www.jstor.org/sta ble/1818155.

[7] Valin H, Sands RD, Van der Mensbrugghe D, Nelson GC, Ahammad H, Blanc E, Bodirsky B, Fujimori S, Hasegawa T, Havlik P, Heyhoe E. The future of food demand: understanding differences in global economic models. Agricultural Economics. 2014 Jan;45(1):51-67.https://doi.o rg/10.1111/agec.12089.

[8] Elferink M, Schierhorn F. Global Demand for Food is Rising. Can we meet it. Harvard Business Review. 2016 Apr 7;7(04):2016.

[9] Liu P. Impacts of foreign agricultural investment on developing countries: evidence from case studies. FAO Commodity and Trade Policy Research Working Papers, no. 47. 2014.
[10] FAO/WFP/IFAD. 2012. The State of food insecurity in the world 2012: economic growth is necessary but not sufficient to accelerate reduction of hunger and malnutrition. Rome: Food and Agriculture Organization; 2012.

[11] Power, G., Gardaz, A., \& Dey, J. (2012). Scaling up global food security and sustainable agriculture. United Nations Global Compact Office.

[12] Wooldridge JM. On estimating firm-level production functions using proxy variables to control for unobservables. Economics letters. 2009 Sep 1;104(3):112-4.. https://doi.org/10.1016/j.econlet.2009.04.026.

[13] Barmby T, Sessions J, Treble J. Absenteeism, efficiency wages and shirking. The Scandinavian Journal of Economics. 1994 Dec 1;96(4):561-6. https://doi.org/10.2307/3440797.

[14] Akerlof GA, Yellen JL. The fair wage-effort hypothesis and unemployment. The Quarterly Journal of Economics. 1990 May 1;105(2):255-83. https://doi.org/10.2307/2937787.

[15] Georgiadis A. Efficiency Wages and the Economic Effects of the Minimum Wage: Evidence from a Low-Wage Labour Market. Oxford Bulletin of Economics and Statistics. 2013 Dec; 75(6): 962-79. https://doi.org/10.1111/j.1468-0084.20 12.00713.x.

[16] Draca M, Machin S, Van Reenen J. Minimum wages and firm profitability. Paper 13996. Nber Working Paper Series. National Bureau of Economic Research, Cambridge, MA 02138 May 2008. Retrieved from http://www.nber.org/pape rs/w13996.

[17] Long C, Yang J. How do firms respond to minimum wage regulation in China? Evidence from Chinese private firms. China Economic Review. 2016 Apr 1;38:267-84. https://doi.org/10.1016/j.chieco.2016.01.003.

[18] Izzaty SR, Kebijakan Penetapan Upah Minimum di Indonesia. Jurnal Ekonomi \& Kebijakan Publik. 2013;4(2):131-45.

[19] Chun N, Khor N. Minimum Wages and Changing Wage Inequality in Indonesia (March 2010). Asian Development Bank Economics Working Paper Series No. 196, Available at SSRN: https://ssrn.com/abstract $=1632245$ or http://dx.doi.org/10.2139/ssrn.1632245.

[20] Riley R, Bondibene CR. Raising the standard: Minimum wages and firm productivity. Labour Economics. 2017 Jan 1;44:27-50.. https://doi.org/10.1016/j.labeco.2016.11.010.

[21] Rizov M, Croucher R, Lange T. The UK national minimum wage's impact on productivity. British Journal of Management. 2016 Oct;27(4):819-35.. https://doi.org/10.11 11/1467-8551.12171.

[22] Mollisi V, Rovigatti G. Theory and Practice of TFP Estimation: The Control Function Approach Using Stata (February 11, 2017). CEIS Working Paper No. 399, Available at SSRN: https://ssrn.com/abstract=2916753 or http://dx.doi.org/10.2139/ssrn.2916753.

[23] Riley R, Bondibene CR. Raising the Standard: Minimum Wages and Productivity. NIESR Discussion Paper 449; 2015. 